\title{
Hubungan Pola Asuh Keluarga Dengan Kemandirian Perawatan Diri Anak Usia Sekolah
}

\author{
Hermawati, SKM \\ Email: Hermawatiskm7@gmail.com
}

Dinas Kesehatan Kabupaten Lombok Utara

\begin{abstract}
ABSTRAK
Pola asuh keluarga merupakan suatu cara orangtua dalam mengasuh anak untuk mampu melakukan perawatan diri secara mandiri dengan berbagai tipe pola asuh yang digunakan keluarga yaitu, pola asuh demokratis, permisif, dan otoriter. Anak yang mampu mandiri dalam melakukan perawatan diri dapat meningkatkan derejat kesehatan pada anak usia sekolah dengan anak mampu melakukan dan memenuhi kebutuhan udara, air, nutrisi, eleminasi, pencegahan bahaya, privasi, interaksi sosial, aktivitas dan istirahat. Tujuan penelitian ini untuk mengetahui hubungan pola asuh keluarga dengan kemandirian perawatan diri anak usia sekolah. Metode yang digunakan adalah desain cross sectional. Jumlah sampel penelitian sebanyak 107 orang yang diambil menggunakan teknik cluster proporsional sampling. Hasil penelitian menunjukkan bahwa jenis kelamin anak perempuan, dan pola asuh demokratis dan permisif yang menjadi faktor dominan dalam memandirikan anak dalam melakukan perawatan diri. Pola asuh yang digunakan keluarga dalam mendidik anak merupakan salah ssatu faktor keberhasilan orangtua dalam mendidik dan membesarkan anak, agar menjadikan anak yang berkualitas dikemudian hari dan mampu memberikan implikasi bagi pelaksanaan pelayanan kesehatan bagi anak sekolah dalam membuat suatu program untuk anak usia sekolah.
\end{abstract}

Kata Kunci : Pola Asuh Keluarga, Kemandirian Perawatan Diri, Anak Usia Sekolah.

\section{A. LATAR BELAKANG}

Kualitas sumber daya manusia dipengaruhi oleh pertumbuhan dan perkembangan seseorang, yang dimulai dari bayi, balita, anak, remaja, dewasa sampai dengan lansia. Salah satu tahapan tumbuh kembang yang mempengaruhi kualitas manusia adalah tahap tumbuh kembang anak usia sekolah. Anak usia sekolah adalah anak yang berusia kurang lebih 6 tahun dan diakhiri ketika anak mulai mengalami puberitas yaitu usia 12 tahun [1].

Hasil Sensus Penduduk Indonesia tahun 2010 diketahui bahwa jumlah total penduduk Indonesia sebanyak 237,6 juta jiwa, jumlah penduduk usia sekolah sebanyak 19,3\% (42 juta jiwa). Berdasarkan rentang usia penduduk Indonesia paling banyak pada usia 5-9 tahun sebanyak 23 juta jiwa $(9,78 \%)$, usia 0-4 tahun dan 10-14 tahun masing-masing sebesar 22,6 juta jiwa $(9,54 \%)$ [2]. Jumlah penduduk berdasarkan umur ini, dapat terlihat bahwa jumlah anak usia sekolah cukup banyak sehinggi dibutuhkan peran serta pemerintah dalam upaya meningkatkan derajat kesehatannya.

19 Anak akan mengalami proses tumbuh kembang dengan berbagai macam perubahan yang akan terjadi baik secara fisik, psikososial, kognitif, moral, dan spiritual [1][3]. Pertumbuhan dan perkembangan fisik anak ditandai dengan penambahan TB (tinggi badan), BB (berat badan), dan postur tubuh. Perkembangan kognitif ditandai dengan anak mampu berpikir logis, mampu mengingat, berpikir imajinatif. Perkembangan psikososial anak usia sekolah meliputi adanya pengembangan konsep diri anak menjadi lebih berpikir rasional. Perkembangan moral dan spiritual pada anak usia sekolah ditandai dengan anak mulai mampu berpikir dan memiliki kepribadian yang lebih bersifat abstrak [1]. Kemampuan dan keberhasilan tumbuh 
kembang anak dapat dilihat dari kemandirian anak dalam memenuhi kebutuhan dasarnya [1]. Hurlock [4] menjelaskan bahwa tumbuh kembang yang optimal bertujuan untuk menjadikan anak menjadi manusia yang berkualitas dengan tidak hanya sekedar tumbuh secara fisik, namun juga berkemampuan untuk berdaya guna dan berhasil guna baik bagi dirinya, keluarganya, masyarakat, bangsa serta umat manusia. Oleh karena itu, masa anak-anak perlu mendapatkan perhatian. Pemantauan perkembangan ada empat aspek yang dinilai, yaitu motorik kasar, motorik halus, bahasa, dan personal sosial. Faktor yang mempengaruhi keberhasilan tumbuh kembang anak adalah faktor internal (keluarga, ras, umur, dan lain-lain) dan eksternal (gizi, psikologis, penyakit, dan lainlain) [1].

Karakteristik anak yang sehat yaitu sehat fisik, mental-emosional, mental-intelektual, mental-sosial, dan mental-spiritual [5]. Dalam Roopnaire \& Johnson (1993) Froebel menjelaskan bahwa masa anak merupakan suatu fase yang sangat penting dan berharga, dan merupakan masa pembentukan karakter dan kemandirian anak dalam periode kehidupan manusia.

Gaya pola asuh yang diberikan keluarga akan menunjukkan karakter anak ke depannya. Pola asuh keluarga dan fungsi keluarga sangat penting dalam mengetahui masalah yang terjadi pada anak (Golan dan Enten, 2004). Pola asuh yang telah diterapkan oleh keluarga (suami-istri) bekerja, dan anak tinggal bersama nenek atau pengasuhnya akan sangat berbeda dengan pola asuh yang diterapkan oleh keluarga dengan ibu rumah tangga, yang dapat sepenuhnya mengasuh anaknya. Menurut Baumrind (1967) yang dikutip oleh Petranto [6] pola asuh keluarga merupakan gambaran tentang sikap dan perilaku keluarga dengan anak dalam berinteraksi, serta berkomunikasi dengan anggota keluarga. Kemampuan interpersonal keluarga dengan anak melalui pendekatan secara komprehensif akan mempengaruhi kemandirian anak dalam perawatan dirinya [7].
Ketergantungan anak diakibatkan karena anak merasa keluarga masih bisa membantu anak dalam memenuhi kebutuhannya sehari-hari. Keluarga lebih memanjakan anak karena ingin melindungi anak dan khawatir kebutuhan anak tidak terpenuhi, pada hal kemandirian anak perlu dikembangkan agar merasa aman, bisa beradaptasi dengan baik dan diterima di lingkungan. Keluarga dan perawat komunitas mempunyai peranan yang penting dalam meningkatkan status kesehatan masyarakat terutama pada anak usia sekolah. Peran perawat sebagai care provider dan conselor dibutuhkan dalam membantu keluarga untuk dapat memberikan pola asuh yang tepat unutk memandirikan anak.

Salah satu upaya yang dapat dilakukan dengan memandirikan anak adalah dengan mengajarkan dan memberikan tanggung jawab kepada anak, misalnya membuat jadwal aktivitas sehari-hari anak mulai dari bangun tidur hingga tidur lagi pada malam hari. Kemampuan anak dalam mengatur waktunya akan memberikan dampak positif anak mampu disiplin dan bertanggung jawab pada dirinya sendiri. Pemberian reinforcement positif pada kemandirian anak akan memotivasi anak untuk dapat melakukan hal lebih untuk bisa memandirikan dirinya.

\section{B. METODE PENELITIAN}

Metodologi penelitian yang meliputi rancangan penelitian, populasi dan sampel, tempat penelitian, waktu penelitian, etika penelitian, alat pengumpulan data, uji instrument (validitas dan reliabilitas), prosedur pengumpulan data, pengolahan dan rencana analisis data. Rancangan penelitian membantu peneliti dalam memperoleh jawaban terhadap pernyataan penelitian untuk menguji kesahihan hipotesa, obyektif, akurat sehingga tercapai tujuan penelitian [8].

C. HASIL DAN PEMBAHASAN

1. Gambaran Pola Asuh Keluarga pada Anak Usia Sekolah

Pola asuh permisif merupakan pola asuh yang diberikan orangtua menunjukkan 
kehangatan yang tinggi, bersifat longgar, kurang bimbingan, dan cenderung memanjakan, dan dituruti keinginannya. Sikap orangtua yang menerima apa adanya itu akan cenderung memberikan kebebasan kepada anak untuk berbuat apa saja. Pola asuh ini dapat mengakibatkan mempunyai karakteristik anak impulsive, agresif, tidak patuh, manja, kurang mandiri, mau menang sendiri dan kurang percaya diri [4]. Pola asuh permisif biasanya cenderung tidak menegur atau memperingatkan anak apabila anak sedang dalam bahaya, dan sangat sedikit bimbingan yang diberikan oleh mereka. Namun orangtua tipe ini biasanya bersifat hangat, sehingga seringkali disukai oleh anak [9].

Anak dengan tipe pola asuh permisif, anak akan menunjukkan sifat akan kurang mandiri, dan ada beberapa yang mandiri. Namun hal ini, tidak bisa dijadikan suatu perilaku yang bisa memandirikan anak sesuai standar anak mampu dalam melakukan perawatan diri. Anak mandiri dalam pola asuh permisif, mungkin bisa kita lihat anak mandiri dalam melakukan perawatan diri, apakah sudah cukup atau benar-benar tepat pelaksanaan perawatan diri yang dilakukan. dengan didikan yang lebih membiarkan anak melakukan hal yang diinginkannya, pada penelitian ini membuat anak mampu mandiri untuk melakukan perawatan diri. Pada saat pengambilan data terdapat beberapa anak yang pulang sekolah langsung bermain tanpa mengganti baju sekolah, sudah mandi namun kebersihan bagian tubuh masih ada yang tidak tepat (kuku panjang dan hitam, kuping kurang bersih, dan anak tidak sisiran setelah mandi. Oleh sebab itu perlu diperhatikan oleh orangtua bagaimana anak mampu melakukan perawatan diri dengan apakah sudah benar.

Pola asuh demokratis adalah pola asuh yang bersifat rasional dalam segala pemikiran dan pengambilan keputusan. Orangtua dalam melakukan atau memutuskan suatu putusan selalu tidak ragu-ragu dalam mengendalikan anak mereka, lebih memprioritaskan anak, bersikap realistis terhadap kemampuan anak, tidak berharap memberikan kebebasan kepada anak untuk memilih dan melakukan suatu tindakan dan pendekatannya kepada anak yang bersifat hangat membuat anak merasa nyaman dan dapat belajar dengan baik [7]. Agar mandiri anak diberi kesempatan memilih, menghargai usahanya, hindari banyak bertanya, jangan langsung menjawab pertanyaan, membantu melihat alternatif lain, dan jangan patahkan semangatnya. Pola asuh demokratis menumbuhkan keyakinan dan kepercayaan diri mendorong tindakantindakan mandiri membuat keputusan sendiri akan berakibat munculnya tingkah laku mandiri yang bertanggung jawab. Hasilnya anak akan mandiri, dapat mengontrol diri, dan mempunyai hubungan baik dengan teman, mampu menghadapi stress, mempunyai minat terhadap hal-hal yang baru, dan kooperatif terhadap orang lain. Pola asuh otoriter orangtua cenderung memaksakan standar yang diinginkannya kepada anak, menggunakan hukuman pada tiap kesalahan yang dilakukan anak tanpa mendengarkan alasan kegagalan terjadi. Hal ini sesuai yang dijelaskan pada penelitian Walters (dalam Lindgren, 2001) ditemukan bahwa pola otoriter cenderung menggunakan hukuman terutama hukuman fisik. Sikap otoriter orangtua sering tidak disadari, padahal anak lahir dan bersifat unik yang memiliki kelebihan, kelemahan, minat dan emosi yang berbeda-beda. Pola asuh otoriter cenderung menetapkan standar yang mutlak harus dituruti, biasanya dibarengi dengan ancaman-ancaman. Seperti belajar harus selalu mendapatkan nilai 8 , anak tidak boleh bermain dan harus terus belajar, dalam belajar anak dibiarkan sendiri, dan tidak membantu kesulitan belajar anak. Karakteristik pola asuh otoriter biasanya akan menjadikan anak penakut, pendiam, tertutup, tidak berinisiatif, gemar menentang, dan suka melawan. Hal ini yang membuat terganggunya pertumbuhan dan perkembangan anak secara psikologis ke depannya.
2. Hubungan Pola Asuh Keluarga Dengan Kemandirian Perawatan Diri Anak Usia Sekolah


Pola asuh yang tepat diberikan orangtua kepada anak dalam memandirikan anak dalam melakukan perawatan diri, akan berdampak positif pada anak. Kemampuan anak dalam melakukan perawatan diri secara mandiri akan menjadikan anak yang bertanggung jawab pada tugas, anak akan mandiri melakukan segala hal yang ingin dilakukkannya, dan anak akan berhasil melalui tahap tumbuh kembang sesuai dengan usianya. Orangtua sebaiknya bisa menjadi teman bagi anak, tidak memaksakan kehendak kepada anak, dan memberikan hukuman tanpa mengetahui sebab-akibat dari setiap hukuman yang diberikan. Namun saat ini masih banyak orangtua yang main hakim sendiri kepada anak, membuat keputusan sendiri tanpa bertanya kepada anak tentang keinginan mereka, dan orangtua merasa ialah yang berkuasa penuh dan memiliki hak untuk melakukan hal apa saja kepada anak agar anak mau ikut perintah orangtua.

Menurut penelitian Sari (2006), menjelaskan pola asuh demokratis merupakan pola asuh yang banyak diterapkan orangtua dalam mendidik anak untuk mandiri, tetapi orangtua tetap menetapkan batas dan kontrol. Orangtua biasanya bersikap bijaksana, hangat, penuh kasih sayang, menerima segala alasan dari tiap masalah yang ada, memberikan motivasi dan dukungan kepada anak agar anak mampu mandiri melakukan segala hal (perawatan diri). Menurut peneliti, pola asuh demokratis mampu membuat anak mandiri dalam melakukan perawatan diri secara mandiri dengan melihat teori yang mendukung dan penelitian yang telah dilakukan. pola asuh demokratis lebih bersifat liberal namun terkontrol, ini sesuai dengan tumbuh kembang anak pada usia sekolah yang lebih banyak memiliki keinginan bermain, belajar sambil bermain, anak bisa mengambil suatu makna dari dampak lingkungan yang positif dan didikan orangtua yang bersifat demokratis.

Perawat komunitas penting disini dalam melakukan sosialisasi bentuk pola asuh dan implikasi pola asuh bagi tumbuh kembang anak, pendidikan dan pengetahuan tentang anak, serta bagaimana anak bisa mandiri sesuai usianya. Sehingga memiliki kesimpulan, orangtua bisa memilih tipe pola asuh demokratis dalam mendidik anak, namun jika anak lebih bersikap dan berperilaku negatif, orangtua bisa lebih tegas dengan bersikap otoriter dengan mengimbangi hukuman berdasarkan toleransi dan manusiawi, dan ada kalanya orangtua menggunakan pola asuh permisif, ketika anak mampu berperilaku positif seperti anak berprestasi dimana saja, dengan memberikan atau membebaskan anak untuk memilih hal yang diinginkannya sendiri sesuai batasan.

\section{Gambaran kemandirian perawatan diri anak usia sekolah}

Hasil penelitian diketahui bahwa anak usia sekolah yang mandiri dalam melakukan perawatan diri lebih besar dibanding dengan anak yang tidak mandiri. Hasil penelitian ini sesuai dengan penelitian oleh Julianto (2007) yang menjelaskan bahwa anak usia sekolah SDN Panjang Wetan 01 Pekalongan, sebagian besar mempunyai tingkat kemandirian baik.

Menurut Orem (1991) dalam Meleis (2007), perawatan diri dapat dilakukan oleh siapa saja, baik usia dewasa, remaja, dan anak. Lie dan Prasasti (2006) menjelaskan anak usia 6-12 tahun belajar untuk menjalankan kehidupan sehariharinya secara mandiri. Jika orangtua bisa membimbing anak dengan baik, anak akan belajar makin rajin dan bersemangat melakukan kegiatan-kegiatan yang produktif bagi kemajuan dirinya sendiri. Pada usia 6-12 tahun, anak mulai bisa menerima pendidikan dari luar maupun dalam lingkungan dimana anak tinggal, anak belajar di dalam dan di luar sekolah, serta anak harus menjalani tugas-tugas perkembangan seperti; belajar keterampilan fisik, sikap sehat, bergaul dengan teman-teman sebaya, membentuk keterampilan dasar, membentuk konsep-konsep untuk hidup sehari-hari, memperoleh kebebasan pribadi, dan membentuk hati nurani, nilai moral dan nilai sosial (Gunarsa, 2004). Berdasarkan uraian diatas peneliti berpendapat bahwa anak usia sekolah seharusnya sudah mampu mandiri dalam melakukan perawatan diri. Hal ini dapat 
terlihat dari karakteristik yang dimiliki anak usia sekolah.

Berdasarkan fakta bahwa anak usia asekolah 6-12 tahun, menurut peneliti anak mampu mandiri dalam melakukan perawatan diri. Pada masa ini anaksudah bisa diberi tanggung jawab dalam menerima suatu pekerjaan, terutama pada anak tahap II (kanak-kanak akhir). Pada tugas perkembangan usia sekolah, pada masa ini anak membangun sikap yang sehat mengenai diri sendiri sebagai makhluk yang tumbuh, mengembangkan peran sosial dengan pria atau wanita, dan masa ini juga anak diharapkan memperoleh dasar-dasar pengetahuan untuk membentuk anak yang cerdas dan berilmu. Sebagai seorang perawat komunitas memiliki implikasi untuk bisa memandirikan masyarakat dalam upaya pencegahan timbulnya masalah kesehatan dari usia dini. Promosi kesehatan merupakan salah satu jalan untuk bisa menjembatani perawat dengan masyarakat dalam upaya memandirikan dalam menjaga status kesehatan mulai dari sedini mungkin, memberikan pendidikan kesehatan mengenai perawatan diri yang dimulai dari usia sekolah, sosialisasi program untuk bisa memandirikan anak dengan pola asuh yang tepat yang diberikan keluarga, dan meningkatkan pengetahuan masyarakat (keluarga) tentang tumbuh kembang anak usia sekolah, dan upaya yang dilakukan keluarga agar anak mampu mandiri dalam melakukan perawatan diri secara mandiri

\section{KESIMPULAN}

1. Karakteristik keluarga dalam penelitian ini sebagian besar adalah dari orangtua yang berumur dewasa menengah (36-55 tahun), perempuan, memiliki suku yang berasal dari pulau jawa, tingkat pendidikan rendah, tidak bekerja, dengan penghasilan < UMR 1.400.000,-/ bulan, dan tipe keluarga inti yang terdiri dari ayah, ibu dan anak

2. Pola asuh keluarga dalam memandirikan anak usia sekolah didominasi dengan pola asuh permisif dan demokratis, dan sebagian kecil lagi dengan pola asuh otoriter.
3. Sebagian besar anak usia sekolah pada penelitian ini telah mandiri dalam melakukan perawatan diri.

4. Terdapat hubungan antara pola asuh keluarga dan kemandirian perawatan diri pada anak sekolah, pola asuh demokratis dan permisif lebih banyak membuat anak mandiri dalam melakukan perawatan diri, daripada pola asuh otoriter.

\section{DAFTAR PUSTAKA}

[1] Kozier. B, Erb. G, Berman. A, \& Snyder. S.J. (2010). Buku Ajar Fundamental Keperawatan: Konsep, Proses, \& Praktik. Jakarta: EGC

[2] Badan Pusat Statistik (2012). Perkembangan beberapa indicator utama sosial ekonomi Indonesia. Pada tanggal 9 November 2012.

[3] Wong L. Donna \& Whaley. (2001). Nursing Care Of Infants and Children. 6th. Ed. St. Louis : Mosby.

[4] Hurlock, Elisabeth. 2006. Psikologi Perkembangan Edisi Kelima. Jakarta : Erlangga

[5] Hawari Dadang. (2007). Our Children Our Future DimensiPsikoreligi pada tumbuh kembang anak remaja. Jakarta : FKUI.

[6] Petranto. (2009). Jenis-jenis Pola Asuh Orang Tua. [online] di akses dari http://dwpptrijenewa.is

[7] Santrock W. John. (2004). Life-Span Development. 9th. Ed. Americas : the McGraw-Hill Companies. Santrock, W. John (2003). Adolescence: Perkembangan Remaja (edisi keenam). Jakarta: Erlangga

[8] Sastroasmoro, S \& Ismael, S. (2011). DasarDasar Metodelogi Penelitian Klinis. Edisi Ke-4. Jakarta: Sagung Seto

[9] Petranto, I. (2006). Rasa Percaya Diri Anak adalah pantulan Pola Asuh Orang Tuanya. Online:

http://dwpptrijenewa.isuisse.com/bulletin/?p =32(Accessed 1December 2012). 